\title{
Correction to: low coverage sequencing for repetitive DNA analysis in Passiflora edulis Sims: citogenomic characterization of transposable elements and satellite DNA
}

Vanessa Carvalho Cayres Pamponét ${ }^{1}$, Margarete Magalhães Souza ${ }^{1 *}$, Gonçalo Santos Silva ${ }^{1}$, Fabienne Micheli ${ }^{1,2}$, Cláusio Antônio Ferreira de Melo ${ }^{1}$, Sarah Gomes de Oliveira ${ }^{3}$, Eduardo Almeida Costa ${ }^{4}$ and Ronan Xavier Corrêa ${ }^{1}$

\section{Correction to: BMC Genomics (2019) 20:262}

https://doi.org/10.1186/s12864-019-5576-6

Following publication of the original article [1], the authors reported that one of the authors' names was typeset incorrectly. In this Correction the incorrect and correct author name are shown. The original publication of this article has been corrected.

Originally the author name was published as:

- Pamponét Vanessa Carvalho Cayres

The correct author name is:

- Vanessa Carvalho Cayres Pamponét

\begin{abstract}
Author details
'Departamento de Ciências Biológicas, Universidade Estadual de Santa Cruz (UESC), km 16, Salobrinho, Ihéus, Bahia CEP 45662-900, Brazil. ${ }^{2}$ CIRAD, UMR AGAP, F-34398 Montpellier, France. ${ }^{3}$ Departamento de Botânica, Instituto de Biociências, Universidade de São Paulo (USP), Rua do Matão, 14 - Butantã, São Paulo, SP CEP 05508-090, Brazil. ${ }^{4}$ Núcleo de Biologia Computacional e Gestão de Informações Biotecnológicas (NBCGIB), Universidade Estadual de Santa Cruz (UESC), km 16, Salobrinho, Ilhéus, Bahia CEP 45662-900, Brazil.
\end{abstract}

Received: 9 April 2019 Accepted: 9 April 2019

Published online: 18 April 2019

\section{Reference}

1. Pamponét, et al. BMC Genomics. 2019;20:262 https://doi.org/10.1186/ s12864-019-5576-6.

\footnotetext{
*Correspondence: souzamagg@yahoo.com.br

${ }^{1}$ Departamento de Ciências Biológicas, Universidade Estadual de Santa Cruz (UESC), km 16, Salobrinho, Ilhéus, Bahia CEP 45662-900, Brazil

Full list of author information is available at the end of the article
}

(c) The Author(s). 2019 Open Access This article is distributed under the terms of the Creative Commons Attribution 4.0 International License (http://creativecommons.org/licenses/by/4.0/), which permits unrestricted use, distribution, and reproduction in any medium, provided you give appropriate credit to the original author(s) and the source, provide a link to the Creative Commons license, and indicate if changes were made. The Creative Commons Public Domain Dedication waiver (http://creativecommons.org/publicdomain/zero/1.0/) applies to the data made available in this article, unless otherwise stated. 